\title{
Pemodelan Interaksi Serium(III) dan Air dengan Teori Perhitungan $A b$ Initio serta Penentuan Himpunan Fungsi Basisnya
}

\author{
Eva Vaulina Yulistia Delsy, Tien Setyaningtyas, Ponco Iswanto, Nunik Fitri Utami \\ Program Studi Kimia MIPA UNSOED \\ Jl.Dr.Soeparno Purwokerto 53123 \\ e-mail: evasyamsumar@yahoo.com,
}

\begin{abstract}
Abstrak
Penentuan himpunan fungsi basis (HFB) untuk simulasi ion $\mathrm{Ce}^{3+}$ dalam air telah dilakukan dalam penelitian ini. Penentuan HFB harus dilakukan karena HFB yang tersedia adalah HFB untuk unsur $\mathrm{Ce}(\mathrm{III})$, sedangkan model sistem kimia yang dikaji dalam penelitian ini adalah Ce dalam bentuk ion $\left(\mathrm{Ce}^{3+}\right)$. Penentuan HFB dimulai dengan menerapkan semua HFB Ce yang diusulkan dari web basis set. Pemilihan HFB dilakukan dengan menggunakan dua metode. Pertama, mencocokkan kurva energi interaksi terhadap jarak dengan kurva potensial interaksi dua partikel Lennard-Jones 6-12 (metode scan 2 body). Ke dua, optimasi struktur kompleks $\left[\mathrm{Ce}\left(\mathrm{H}_{2} \mathrm{O}\right) \mathrm{n}\right]^{3+}$ kemudian dibandingkan dengan data eksperimen (metode water cluster). Tidak ada transfer muatan yang terjadi pada interaksi $\mathrm{Ce}^{3+}$ dengan air. HFB $\mathrm{H}$ dan $\mathrm{O}$ ditetapkan menggunakan DZP Dunning. Jenis simulasi Dinamika Molekuler yang direkomendasikan untuk mengkaji ion $\mathrm{Ce}^{3+}$ di dalam air adalah MK/MM dengan menggunakan HFB Stutgard RSC ANO/ECP dan Quantum Mechanical Charge Field (QMCF) dengan menggunakan HFB SBKJC VDZ ECP pada tingkat teori Hartree-Fock (HF).
\end{abstract}

Kata Kunci : HFB, ion $\mathrm{Ce}^{3+}$, Lennard Jones, scan 2 body, Water Cluster, Hartree Fock, QCMF

\begin{abstract}
Determination of the set of basis function (HFB) for the simulation of $\mathrm{Ce}^{3+}$ ion in water has been performed in this study. The determination must be made because the HFB is the HFB available for $\mathrm{Ce}(\mathrm{III})$ element, while the model chemical systems studied in this research is in the form of Ce ions $\left(\mathrm{Ce}^{3+}\right)$. Determination HFB is starting by applying all of the proposed Ce web basis set. HFB election conducted using two methods. First, the interaction energy curve to match the distance with a twoparticle interaction potential curve of Leonard-Jones 6-12 (2 body scan method). Second, optimization of the complex structure of $\left[\mathrm{Ce}\left(\mathrm{H}_{2} \mathrm{O}\right) n\right]^{3+}$ and compared with experimental data (method of water cluster). There is no charge transfer occurred in the interaction of $\mathrm{Ce}^{3+}$ with water. $\mathrm{HFB}$ of $\mathrm{H}$ and $\mathrm{O}$ are set using DZP Dunning. This type of simulation Molecular Dynamics is recommended to assess the ion $\mathrm{Ce}^{3+}$ in water is MK/MM using the HFB Stutgard RSC ANO/ECP and Quantum Mechanical Charge Field (QMCF) by using the HFB SBKJC VDZ ECP at Hartree-Fock (HF) theory.
\end{abstract}

Keywords : HFB, $\mathrm{Ce}^{3+}$ ion, Lennard Jones, 2 body scan, Water Cluster, Hartree Fock, QCMF

\section{PENDAHULUAN}

Air merupakan penyusun utama dalam sel (sekitar 70\%) dan merupakan unsur yang menentukan bagi semua sel. Hidrasi ion dalam tubuh terjadi ketika mengkonsumsi mineral.
Mineral akan mengalami hidrasi dan ionisasi sebelum menjalankan proses metabolisme dalam tubuh. Hidrasi ion merupakan peristiwa dimana ion terlarut dikelilingi oleh molekul air. Hidrasi akan menstabilkan ion dan menyebabkan kristal menjadi larut. Hidrasi ini akan meningkatkan 
ukuran efektif dari ion (Holum, 1998). Oleh karena itu hidrasi ion menjadi topik penelitian yang menarik dan penting untuk dikaji.

Beberapa ion logam yang banyak dibutuhkan dalam proses biologi misalnya untuk menjalankan sistem syaraf dan mengaktifkan enzim adalah logam golongan transisi. Logam transisi yang banyak dikembangkan dalam pengobatan adalah kromium $\left(\mathrm{Cr}^{3+}\right)$ yang digunakan untuk kerja insulin dan metabolisme glukosa, zink $\left(\mathrm{Zn}^{2+}\right)$ untuk menstabilkan bentuk konformasi dari berbagai protein dan meningkatkan imunitas tubuh, mangan $\left(\mathrm{Mn}^{2+}\right)$ untuk aktifitas beberapa enzim pada metabolisme karbohidrat (Holum, 1998). Logam lainnya yang juga mulai dikembangkan sebagai senyawa obat adalah logam tanah jarang (LTJ). Serium (Ce) merupakan salah satu unsur LTJ yang banyak dikembangkan dalam aplikasi biomedis seperti perlindungan elemen sel primer dari terapi yang menggunakan radiasi, mencegah kerusakan retina dari peroksida intraseluler dan perlindungan terhadap saraf tulang belakang (Patil et al., 2006). Senyawaan Serium(III) memiliki fungsi yang sangat penting, seperti Serium (III) oksalat yang digunakan sebagai obat kanker dan anti mual.

Kajian sifat struktur dan dinamika hidrasi ion logam sangat penting karena berkaitan dengan sifat koordinasi dan reaktivitas ion logam tersebut di dalam larutan. Penelitian yang mengkaji sifat struktur dan dinamika hidrasi ion logam telah dilakukan dengan alat antara lain Extended X-ray Absorption Fine Structure (EXAFS), large-angle X-ray diffraction (LAXS) dan nuclear magnetic resonance (NMR) (Rode, 2004), namun alat-alat tersebut memiliki keterbatasan yaitu tidak dapat mengamati pertukaran ligan yang cepat. Proses pertukaran ligan dari lapisan hidrasi satu ke lapisan lainnya merupakan parameter dinamika yang penting untuk diamati karena terkait dengan reaktivitas ion (Armunanto, 2003). Masalah keterbatasan tersebut dapat diatasi dengan eksperimen komputer (kimia komputasi). Eksperimen komputer dapat menjembatani antara eksperimen dan teori.

Kemampuan eksperimen komputer meningkat seiring dengan kemajuan komputer dan dapat digunakan untuk sistem yang kompleks (Witoelar, 2002). Metode eksperimen komputer yang digunakan untuk menentukan sifat hidrasi ion adalah simulasi Dinamika Molekular (DM) dan Monte Carlo (MC) (Remsungnen, 2004). Metode MC memberikan gambaran tentang struktur dan energi dalam kesetimbangan, namun tidak dapat memberikan gambaran dinamika atau sifat yang bergantung pada waktu. Metode DM dapat menggambarkan sifat dinamika suatu ion. Simulasi DM telah dikembangkan seiring meningkatnya akurasi dan optimalisasi kebutuhan perhitungan di komputer, yaitu simulasi DM klasik, Car Parrinello (CPMD), Mekanika Kuantum/Mekanika Molekular (MK/MM) dan Quantum Mechanical Charge Field (QMCF). Kajian dilakukan dengan simulasi komputer, namun peristiwa yang terjadi di dalam sistem larutan seperti interaksi antara zat terlarut dengan pelarut, juga harus dimodelkan secara akurat. Metode perhitungan kimia komputasi yang akurat untuk pemodelan molekul adalah $a b$ initio (Rode, 2006). Jika metode ab initio digunakan, maka penentuan Himpunan Fungsi Basis (HFB) yang sesuai dengan model interaksi zat terlarut-pelarut harus dilakukan karena HFB yang tersedia adalah HFB untuk unsur. Ada dua cara yang dapat dilakukan. Pertama, mencocokkan kurva energi interaksi terhadap jarak dengan kurva potensial interaksi dua partikel Lennard-Jones 6-12. Kurva potensial Lennard-Jones 6-12 ditunjukan pada Gambar 1.

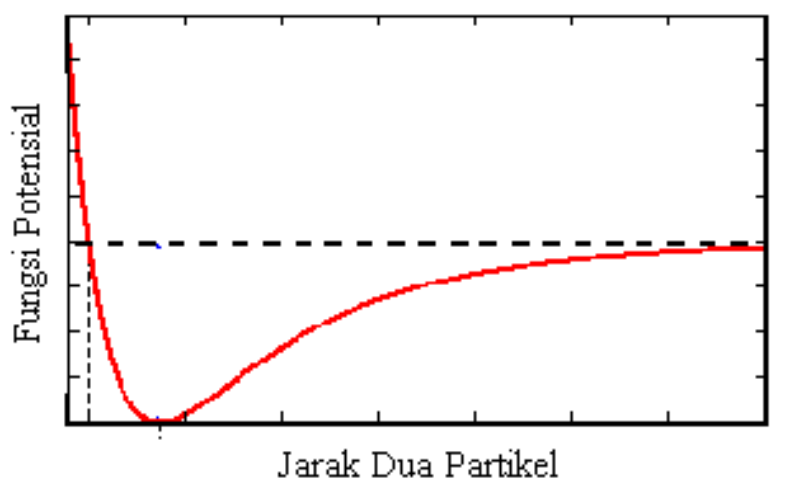

Gambar 1. Kurva Potensial Lennard-Jones 6-12

Kedua, dengan optimasi struktur kompleks $\left[\mathrm{M}\left(\mathrm{H}_{2} \mathrm{O}\right)_{\mathrm{n}}\right]^{\mathrm{m}+}$ dimana $\mathrm{n}=$ jumlah molekul air, $\mathrm{M}=$ ion logam sebagai ion pusat dan $m=$ muatan ion logam (Remsungnen, 2004). Struktur kompleks teroptimasi kemudian dicocokan dengan data geometri hasil percobaan 
seperti jarak ion logam dengan air dan data sudut.

Penelitian ini dilakukan untuk mencari HFB yang sesuai untuk model interaksi ion $\mathrm{Ce}^{3+}$ dengan air. Kajian ini juga diharapkan dapat mendeteksi ada atau tidaknya peristiwa transfer muatan yang dapat mempengaruhi perhitungan energi interaksi serta menggambarkan model atau pola yang terjadi pada interaksi $\mathrm{Ce}^{3+}$-air. Hasil kajian ini diharapkan dapat memberi rekomendasi penggunaan jenis simulasi DM untuk simulasi ion $\mathrm{Ce}^{3+}$ dalam air.

\section{METODE PENELITIAN}

\section{Bahan dan Alat Penelitian}

Penelitian ini merupakan penelitian teoritik yang menggunakan satu ion logam transisi $\mathrm{Ce}^{3+}$ serta model molekul air $\left(\mathrm{H}_{2} \mathrm{O}\right)_{n}$ dengan $\mathrm{n}=1,2,3, \ldots, 6$. Seperangkat komputer Processor Intel Pentium 4 3,0GHz, Hard Disk 512MB, RAM 80GB, program GaussView untuk menggambarkan molekul $\mathrm{Ce}^{3+}-\left(\mathrm{H}_{2} \mathrm{O}\right)_{\mathrm{n}}$, serta program Gaussian 98W dan Gaussian 03W (Foresman dan Frisch 1996).

\section{Prosedur Kerja}

\section{Pencarian HFB kandidat}

$\mathrm{HFB}$ untuk unsur $\mathrm{Ce}$ dan $\mathrm{O}-\mathrm{H}$ (Air) dilihat pada pustaka Web Basis Set dengan alamat https://bse.pnl.gov

\section{Perhitungan Energi Interaksi terhadap jarak dengan metode scan 2-body}

Konfigurasi tiga dimensi 1 ion $\mathrm{Ce}^{3+}$ yang saling berhubungan dengan 1 molekul air digambarkan dengan menggunakan program Gauss View. Perhitungan energi single point kemudian dilakukan dengan kondisi tingkat teori $\mathrm{HF}$, charge $=3$, spin multiplicity $=2$ dan menggunakan HFB kandidat. HFB yang tidak menghasilkan transfer muatan selama perhitungan energi single point digunakan untuk menghitung energi interaksi. Energi interaksi dihitung dengan pendekatan supramolekular:

$$
E_{\text {int eraksi }}=E_{\text {kompleks }}-E_{C e(I I I)}-E_{\text {air }}
$$

$E_{\text {interaksi }}$ adalah energi interaksi untuk interaksi $\mathrm{Ce}^{3+}$-air. $E_{\text {kompleks }}$ adalah energi dari kompleks $\mathrm{Ce}^{3+}-\mathrm{H}_{2} \mathrm{O}$. $E_{C e(I I I)}$ adalah energi single point ion $\mathrm{Ce}^{3+}$ dalam konfigurasi kompleks tanpa molekul air. $E_{\text {air }}$ adalah energi single point semua molekul air dalam kompleks tanpa ion $\mathrm{Ce}^{3+}$. Selain perhitungan energi single point, diberikan variasi jarak kompleks $\mathrm{Ce}^{3+}-\mathrm{H}_{2} \mathrm{O}$ yaitu $1,6,1,8 ; 2,0 ; 2,2 ; 2,4 ; 2,6 ; 2,8 ; 3,0 ; 3,2 ; 3,4 ; 3,6$; 3,$8 ; 4,0 ; 4.5 ; 5,0 ; 5,5 ; 6,0 ; 6,5 ; 7,0 ; 7,5 ; 8,0 ; 9,0$ dan 10,0 ̊̀ untuk masing-masing HFB yang digunakan.

\section{Perhitungan data geometri optimum interaksi ion $\mathrm{Ce}^{3+}$-air metode water cluster}

Metode yang digunakan untuk perhitungan interaksi air-ion logam yang mengalami transfer muatan adalah water cluster. Pertama, konfigurasi tiga dimensi 1 ion $\mathrm{Ce}^{3+}$ yang saling berhubungan dengan 1 molekul air digambarkan. Kemudian geometri interaksi ini dioptimasi dengan kondisi seperti metode scan 2-body. Perlakuan ini diulangi terhadap interaksi antara $1 \mathrm{Ce}^{3+}$ dengan 2,3,4,5 dan 6 molekul air. Energi interaksi dihitung dengan pendekatan supramolekular:

$$
E_{\text {int eraksi }}=E_{\text {kompleks }}-E_{C e(I I I)}-E_{\text {air }}
$$

$E_{\text {interaksi }}$ adalah energi interaksi untuk interaksi $\mathrm{Ce}^{3+}$-air tertentu. $E_{\text {kompleks }}$ adalah energi dari kompleks $\mathrm{Ce}\left(\mathrm{H}_{2} \mathrm{O}\right)_{\mathrm{n}}$ (dimana $\mathrm{n}=1,2,3,4,5$ dan 6). $E_{C e(I I I)}$ adalah energi single point ion $\mathrm{Ce}^{3+}$ dalam konfigurasi kompleks tanpa molekul air dan $E_{a i r}$ adalah energi single point semua molekul air dalam kompleks tanpa ion $\mathrm{Ce}^{3+}$. Selain perhitungan optimasi geometri, rata-rata jarak $\mathrm{Ce}^{3+}-\mathrm{O}$ dicatat untuk masing-masing kompleks.

\section{Penentuan HFB yang cocok untuk interaksi $\mathrm{Ce}^{3+}$-air}

Penelitian ini menghasilkan dua jenis data perhitungan yaitu menggunakan metode scan 2-body dan water cluster. Untuk metode scan 2-body, data hasil perhitungan yang meliputi jarak, $E_{\text {kompleks }}, E_{C e(I I I)}, E_{\text {air, }}$ dan $E_{\text {interaksi }}$ yang didapatkan kemudian di plot sesuai kurva 
energi interaksi terhadap jarak. Apabila kurva energi terhadap jarak yang didapatkan mendekati kurva Lennard Jones 6-12 maka HFB tersebut dinyatakan sesuai untuk interaksi ion $\mathrm{Ce}^{3+}$-air. Data perhitungan dengan metode water cluster dicocokan dengan data percobaan jarak Ce-O. HFB yang terpilih yaitu HFB yang paling mendekati data percobaan.

\section{Penentuan tingkat teori perhitungan untuk kompleks $\left[\mathrm{Ce}\left(\mathrm{H}_{2} \mathrm{O}\right)_{n}\right]^{3+}$}

Tingkat teori perhitungan $a b$ initio Hartree-Fock (HF), Møller-Plesset second-order (MP2) dan Couple Cluster Single and Doubles (CCSD) diterapkan pada HFB terpilih untuk interaksi ion $\mathrm{Ce}^{3+}$-air. Proses optimasi kemudian dilakukan menggunakan tingkat teori perhitungan tersebut. Jarak $\mathrm{Ce}^{3+}$-air yang dioptimasi dibandingkan dengan data eksperimen. Apabila jarak $\mathrm{Ce}^{3+}$-air mendekati nilai eksperimen maka tingkat teori perhitungan tersebut dapat digunakan untuk kompleks $\left[\mathrm{Ce}\left(\mathrm{H}_{2} \mathrm{O}\right)_{n}\right]^{3+}$. Cara lain yang dapat dilakukan adalah dengan melihat data energi interaksi. Jika nilai energi interaksi HF, MP2 dan CCSD tidak jauh berbeda, maka tingkat teori perhitungan yang paling rendah yang dipilih karena tidak membutuhkan waktu perhitungan yang lama.

\section{Rekomendasi jenis simulasi DM yang dapat digunakan untuk simulasi $\mathrm{Ce}^{3+}$ di dalam air}

Pemberian rekomendasi jenis simulasi DM dilakukan dengan melihat kurva energi terhadap jarak yang didapatkan dengan metode scan 2-body dan ada atau tidaknya transfer muatan selama perhitungan energi. Apabila kurva yang didapatkan sesuai kurva Lennard digunakan untuk interaksi ion $\mathrm{Ce}^{3+}$ di dalam air adalah metode MK/MM dan QMCF. Apabila kurva yang didapatkan tidak sesuai kurva Lennard Jones 6-12 maka jenis simulasi DM yang dapat digunakan untuk interaksi ion $\mathrm{Ce}^{3+} \mathrm{di}$ dalam air adalah metode QMCF. Jika ada transfer muatan selama perhitungan energi maka jenis simulasi yang dapat digunakan adalah QMCF.

\section{HASIL DAN PEMBAHASAN}

\section{HFB Kandidat}

HFB yang dipakai dalam penelitian diperoleh dari alamat website https://bse.pnl.gov. HFB $\mathrm{H}$ dan $\mathrm{O}$ ditetapkan menggunakan DZP Dunning (Armunanto, 2003), sedangkan HFB Ce dipilih dari kandidat yang telah ditetapkan oleh website tersebut. HFB untuk unsur $\mathrm{Ce}$ dipilih yang memiliki ECP (effective core potential) yaitu CRENBL ECP, SBKJC VDZ ECP, Stutgart RSC 1997 ECP, Stutgart RSC ANO/ECP, Stutgart RSC Segmented/ECP. ECP akan membuat waktu perhitungan menjadi lebih cepat karena memfokuskan perhitungan hanya pada elektron valensi dan menunjukan potensial efektif yang dimiliki oleh elektron inti (Alkauskas, 2004).

\section{HFB untuk MK/MM}

Transfer muatan yang terjadi selama perhitungan energi dilakukan dengan melihat nilai spin density. Transfer muatan terjadi jika nilai spin density berkurang atau bertambah 0,5 selama perhitungan energi kompleks. Penentuan ada atau tidaknya transfer muatan penting untuk dilakukan karena pada jarak $\mathrm{Ce}^{3+}-\mathrm{H}_{2} \mathrm{O}$ yang lebih besar akan memberikan nilai energi yang lebih negatif dari energi sebenarnya, seperti yang terjadi pada penelitian yang dilakukan oleh Remsungnen (2004). Gambar 2 menunjukan adanya transfer muatan (kurva titik-titik) yang terjadi pada $\mathrm{Fe}^{3+}$ dengan menggunakan HFB Stutgart ECP yang dimodifikasi, kurva garis putus-putus merupakan kurva yang dihasilkan dengan HFB Stutgart ECP dan kurva garis penuh merupakan kurva fungsi pasangan potensial (Remsungnen, 2004). Tidak adanya transfer muatan selama perhitungan energi merupakan syarat penggunaan metode DM MK/MM (scan 2-body). Hasil penelitian menunjukan bahwa tidak terjadi transfer muatan selama perhitungan energi dengan HFB kandidat sehingga metode scan 2-body dapat digunakan. 


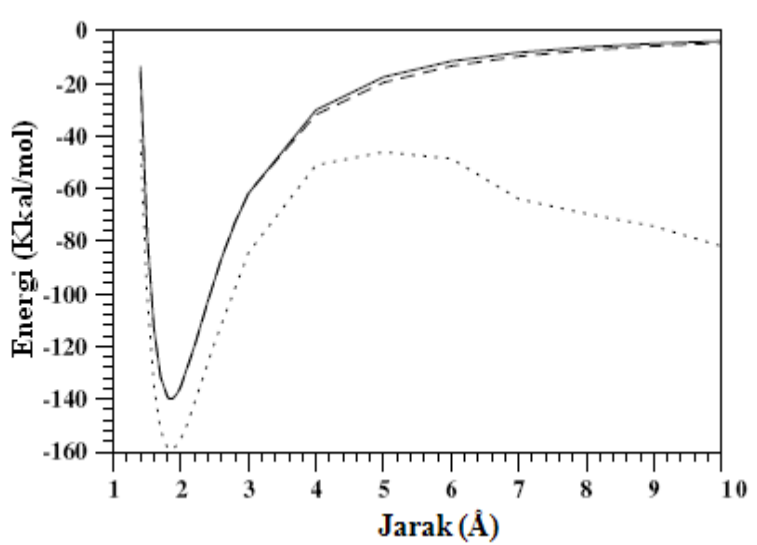

Gambar 2. Kurva energi interaksi terhadap jarak $\mathrm{Fe}^{3+}-\mathrm{O}$ menggunakan HFB Stutgart ECP untuk $\mathrm{Fe}^{3+}$ dan DZP Dunning untuk Air

Penentuan HFB perlu dilakukan karena HFB yang tersedia adalah HFB untuk unsur Ce, sedangkan model sistem kimia yang dikaji dalam penelitian ini adalah Ce dalam bentuk ion $\left(\mathrm{Ce}^{3+}\right)$. Penentuan HFB dengan metode scan 2-body dilakukan dengan memplot energi interaksi terhadap variasi jarak $\mathrm{Ce}^{3+}-\mathrm{H}_{2} \mathrm{O}$. Hasil yang didapatkan dicocokan dengan kurva potensial Lennard-Jones 6-12. Gambar 3 menunjukan kurva energi interaksi terhadap jarak $\mathrm{Ce}-\mathrm{O}$ hasil perhitungan dengan HFB terbaik, yaitu Stutgart RSC ANO/ECP (untuk ion $\mathrm{Ce}^{3+}$ ) dan DZP Dunning (untuk air).

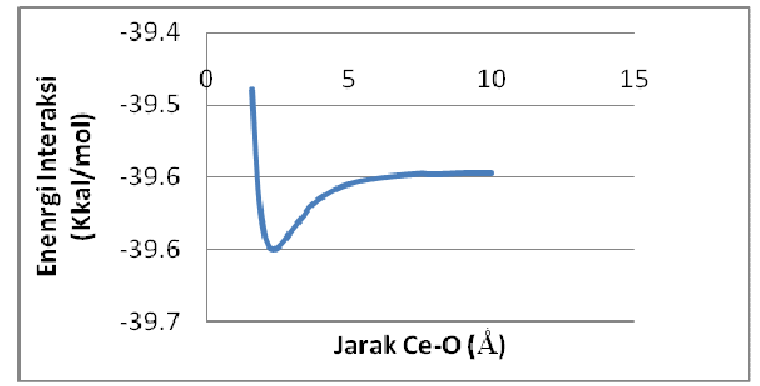

Gambar 3. Kurva energi interaksi terhadap jarak CeO menggunakan HFB Stutgart RSC ANO/ECP untuk $\mathrm{Ce}^{3+}$ dan DZP Dunning untuk Air, dengan Metode Perhitungan Ab Initio

Hasil penelitian ini sesuai dengan penelitian yang dilakukan oleh Remsungnen (2004) yang menggunakan metode scan 2-body untuk menentukan HFB yang dapat digunakan untuk mengkaji simulasi ion $\mathrm{Fe}^{2+}$ dalam air. Garis putus-putus pada Gambar 4. merupakan kurva energi yang didapatkan dengan menggunakan HFB Stutgart ECP. Plot titik-titik merupakan kurva energi yang didapatkan dengan menggunakan modifikasi HFB Stutgart ECP. Kedua kurva kemudian dibandingkan dengan profil kurva fungsi pasangan potensial (kurva garis penuh).

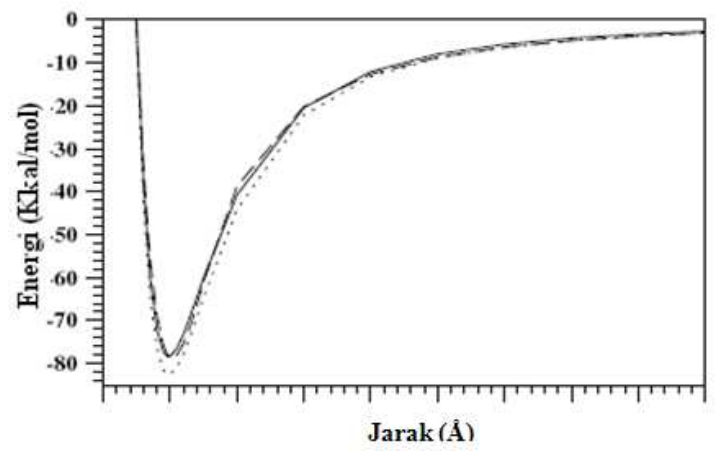

Gambar 4. Kurva energi interaksi terhadap jarak $\mathrm{Fe}^{2+}-\mathrm{O}$ menggunakan HFB Stutgart ECP untuk $\mathrm{Fe}^{2+}$ dan DZP Dunning untuk Air

\section{HFB untuk QMCF}

Berbagai tingkat teori perhitungan $a b$ initio dapat mempengaruhi lama perhitungan. HF hanya menghitung rata-rata interaksi elektron, dan mengabaikan korelasi antara elektron. MP2 menghitung interaksi antara elektron dalam sistem yang dimodelkan sehingga membutuhkan waktu yang lebih lama dibandingkan dengan HF. CCSD menghitung energi dan optimasi ganda sehingga membutuhkan waktu lebih banyak daripada MP2. Durasi perhitungan berbeda-beda untuk tiap tingkat teori. Sebagai contoh SBKJC VDZ ECP membutuhkan waktu 2 menit untuk HF, 8 menit untuk MP2 dan 51 menit untuk CCSD. Penentuan HFB dengan metode water cluster dilakukan dengan mengoptimasi kompleks $\left[\mathrm{Ce}\left(\mathrm{H}_{2} \mathrm{O}\right)_{\mathrm{n}}\right]^{3+}$. Kompleks Ce- $\mathrm{H}_{2} \mathrm{O}$ hanya dapat teroptimasi dengan menggunakan HFB SBKJC VDZ ECP dan Stutgart RSC Segmented/ECP. Jarak Ce-O dibandingkan dengan data eksperimen menggunakan XRD (Tabel 1.) 
Tabel 1. Perbandingan jarak Ce-O antara dua HFB dengan tingkat teori berbeda dengan data eksp

\begin{tabular}{|l|l|l|l|}
\hline \multirow{2}{*}{ HFB } & \multicolumn{3}{|l|}{ Jarak Ce-O $(\AA)$} \\
\cline { 2 - 4 } & HF & MP2 & CCSD \\
\hline & & & \\
SBKJC VDZ ECP & 2,34 & 2,30 & 2,32 \\
\hline $\begin{array}{l}\text { Stutgart RSC } \\
\text { Segmented/ECP }\end{array}$ & 2,31 & 2,25 & \\
\hline Data Eksperimen & \multicolumn{3}{|c|}{$2,210-2,513$} \\
\hline
\end{tabular}

Data eksperimen menunjukan bahwa $\mathrm{Ce}^{3+}$ memiliki jarak rata-rata $\mathrm{Ce}-\mathrm{O}$ adalah 2,210$2,513 \AA$ Á (Feng et al., 2009). Jarak Ce-O yang didapatkan tidak berbeda jauh dengan data eksperimen. HFB dan tingkat teori perhitungan terpilih berturut-turut adalah SBKJC VDZ ECP dan HF karena tidak membutuhkan waktu perhitungan yang lama. Tingkat teori HF juga telah digunakan pada beberapa interaksi ion-air seperti ion $\mathrm{Al}^{3+}$ (Hofer, 2008).Metode water cluster juga menghasilkan data energi interaksi. Tabel 2 menunjukan pengaruh jumlah molekul air terhadap jarak optimum $\mathrm{Ce}^{3+}-\mathrm{O}$.

Tabel 2. Energi interaksi Ce-air dengan SBKJC VDZ ECP pada tingkat teori $\mathrm{HF}$

\begin{tabular}{|l|l|l|}
\hline $\begin{array}{l}\mathrm{HFB} \text { SBKJC } \\
\text { VDZ ECP }\end{array}$ & $\begin{array}{l}\text { Energi } \\
\text { Interaksi } \\
(\mathrm{kkal} / \mathrm{mol})\end{array}$ & Jarak Ce-O \\
\hline $\mathrm{Ce}-1 \mathrm{H}_{2} \mathrm{O}$ & $-40,08$ & 2,34 \\
\hline $\mathrm{Ce}-2 \mathrm{H}_{2} \mathrm{O}$ & $-77,80$ & 2,43 \\
\hline $\mathrm{Ce}-6 \mathrm{H}_{2} \mathrm{O}$ & $-241,25$ & 2,54 \\
\hline
\end{tabular}

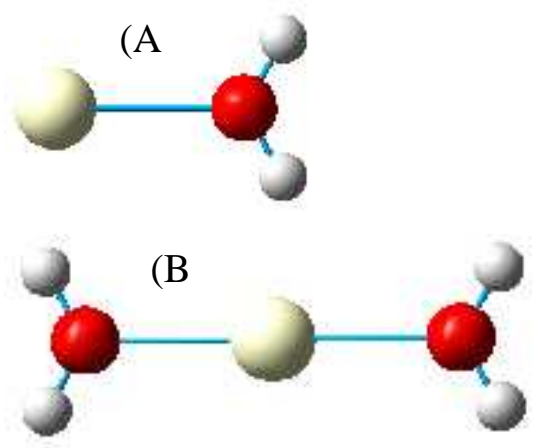

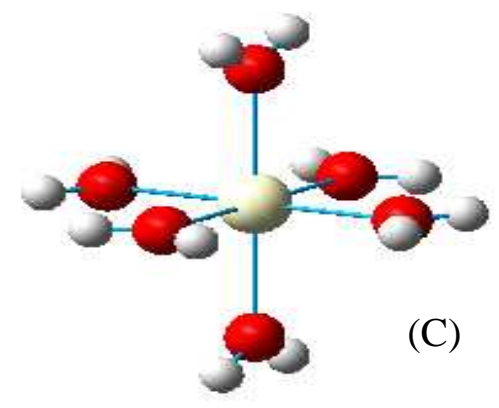

Gambar 5. Konfigurasi optimum $(\mathrm{A})=\left[\mathrm{CeH}_{2} \mathrm{O}\right]^{3+}$, $(\mathrm{B})=\left[\mathrm{Ce}\left(\mathrm{H}_{2} \mathrm{O}\right)_{2}\right]^{3+},(\mathrm{C})=\left[\mathrm{Ce}\left(\mathrm{H}_{2} \mathrm{O}\right)_{6}\right]^{3+}$ dengan menggunakan HFB SBKJC VDZ ECP pada tingkat teori $\mathrm{HF}$

Semakin banyak molekul air yang terikat pada $\mathrm{Ce}$ akan meningkatkan energi interaksi. Jarak Ce-O meningkat seiring dengan bertambahnya jumlah molekul air. Hal ini dikarenakan semakin banyak interaksi antara ligan dengan logam dan ligan dengan ligan (Remsungnen, 2004).

\section{Rekomendasi Jenis Simulasi DM yang Dapat Digunakan untuk Simulasi Ion $\mathrm{Ce}^{3+}$ dalam Air}

Hasil penelitian dengan metode scan 2body menunjukan kurva energi interaksi terhadap jarak menggunakan HFB Stutgart RSC ANO/ECP pada tingkat teori HF sesuai dengan kurva Lennard Jones 6-12. Jenis simulasi DM $\mathrm{MM} / \mathrm{MK}$ dapat digunakan untuk simulasi ion $\mathrm{Ce}^{3+}$ dalam air dengan menggunakan HFB dan tingkat teori perhitungan tersebut. Jenis simulasi yang juga dapat digunakan untuk simulasi ion $\mathrm{Ce}^{3+}$ dalam air adalah metode $\mathrm{QMCF}$ dengan menggunakan HFB SBKJC VDZ ECP pada tingkat teori perhitungan HF.

\section{KESIMPULAN DAN SARAN}

\section{Kesimpulan}

1. Tidak terjadi transfer muatan selama perhitungan energi interaksi $\mathrm{Ce}^{3+}$-air dengan HFB CRENBL ECP, SBKJC VDZ ECP, Stutgart RSC 1997 ECP, Stutgart RSC ANO/ECP, Stutgart RSC Segmented/ECP. 
2. Jenis simulasi DM yang direkomendasikan untuk mengkaji ion $\mathrm{Ce}^{3+}$ didalam air adalah MK/MM dengan menggunakan HFB Stutgart RSC ANO/ECP pada tingkat teori HF dan QMCF dengan menggunakan HFB SBKJC VDZ ECP pada tingkat teori HF.

\section{Saran}

Perlu dilakukan simulasi ion $\mathrm{Ce}^{3+} \mathrm{di}$ dalam air untuk mengetahui geometri kompleks $\left[\mathrm{Ce}\left(\mathrm{H}_{2} \mathrm{O}\right) \mathrm{n}\right]^{3+}$ dan kekuatan interaksi ion $\mathrm{Ce}^{3+}$ dengan molekul air.

\section{UCAPAN TERIMAKASIH}

Penulis mengucapkan terima kasih atas kerja samanya kepada :

1. Austrian-Indonesian Center for Computational Chemistry(AIC) Kimia UGM Yogyakarta

2. Soedirman Group for Computational Chemistry (SGC) Kimia UNSOED Purwokerto

\section{DAFTAR PUSTAKA}

1. Alkauskas, A., A. Baratoff and C. Bruder, 2004, Gaussian form of Effective Core Potential and Response Function Basis Set Derived from Troullier-Martins Pseudopotential: Results for $\mathrm{Ag}$ and $\mathrm{Au}$,http://quantumtheory.physik.unibas.ch/br uder/audriusphyschem.pdf, diakses 11 November 2009.

2. Armunanto, R., C.F. Schwenk, A.H.B. Setiaji and B.M. Rode, 2003, Classical and QM/MM molecular dynamics simulations of $\mathrm{Co}^{2+}$ in water, Chemical Physics Letters 295: 63.

3. Foresman, J.B. and Æ. Frisch, 1996, Exploring Chemistry with Electronic Structure Methods $2^{\text {nd }}$ Edition, Gaussian Inc, USA.

4. Feng, X., J.S. Zhao, X.G. Shi, F. Ruan and L.Y. Wang, 2009, Crystal structure of triaqua-(pyrazine-2,3-

dicarboxylato)cerium(III),
$\mathrm{Ce}(\mathrm{H} 2 \mathrm{O}) 3(\mathrm{C} 6 \mathrm{H} 2 \mathrm{~N} 2 \mathrm{O} 4), \quad \mathrm{CCDC}$ no. $1267 / 2654$.

5. Hofer, T.S., B.R. Randolf, and B.M. Rode, 2008, Al(III) Hydration Revisited. An ab Initio Quantum Mechanical Charge Field Molecular Dynamics Study, J. Phys. Chem. B 112: 11726-11733.

6. Holum, J.R., 1998, Fundamentals of General, Organic and Biological Chemistry, John Wiley and Sons Inc, USA.

7. Patil, S., Amanda S., Eric H., William S. and Sudipta S., 2006, Protein Adsorption and Cellular Uptake of Cerium Oxide Nanoparticles as a Function of Zeta Potential, Journal Biomaterials. 28(31): 4600-4607.

8. Remsungnen, T., and B.M. Rode, 2004, Molecular Dynamics Simulation of the Hydration of Transition Metal Ions: the Role of Non-Additive Effects in the Hydration Shells of $\mathrm{Fe}^{2+}$ and $\mathrm{Fe}^{3+}$ Ions, Chemical Physics Letters 385: 491.

9. Rode, B.M., Chinapong K., Kristof P., 2004, Structure and Dynamics of the Cr(III) Ion in Aqueous Solution: Ab Initio QM/MM Molecular Dynamics Simulation, Wiley InterScience, Online.

10. Rode, B.M. and T.S. Hofer, 2006, How to Access Structure and Dynamics of Solution: the Capabilities of Computational Methods, Pure Appl. Chem., Vol. 78, No. 3, pp. 525

11. Witoelar, A., 2002, Perancangan dan Analisa Simulasi Dinamika Molekul Ensemble Mikrokanonikal dan Kanonikal dengan Potensial Lennard Jones, http://www.witoelar.com/aree/tech/Simulasi Dinamika Molekul.pdf, diakses tanggal 7 November 2009. 